\title{
BỆNH THậN ĐÁI THÁO ĐƯờNG: VẤN ĐỀ CẦ QUAN TÂM
}

Đinh Thị Minh Hảo, Trần Thị Anh Thur

Khoa Nội Thận-CXK, Bệnh viện Trung uoong Huế

DOI: $10.47122 / v j d e .2020 .38 .2$

\section{ABSTRACT \\ Diabetic nephropathy: \\ Matters for pay attention}

Diabetic nephropathy is a serious kidneyrelated complication of type 1 diabetes and type 2 diabetes. It is also called diabetic kidney disease. About $25 \%$ of people with diabetes eventually develop kidney disease. Diabetic nephropathy affects your kidneys' ability to do their usual work of removing waste products and extra fluid from your body. The best way to prevent or delay diabetic nephropathy is by maintaining a healthy lifestyle and treating your diabetes and high blood pressure. Over many years, the condition slowly damages your kidneys' delicate filtering system. Early treatment may prevent or slow the disease's progress and reduce the chance of complications. Kidney disease may progress to kidney failure, also called end-stage kidney disease. Kidney failure is a life-threatening condition. At this stage your treatment options are dialysis or a kidney transplant.

Key words: Diabetic nephropathy, kidney failure

\section{TÓM TẮT}

Bệnh thận đái tháo đường (ĐTĐ) là một biến chứng nghiêm trọng của ĐTĐ típ 1 và típ 2 có liên quan đến thận. Nó còn được gọi là bệnh thận do ĐTĐ. Khoảng $25 \%$ những người mắc bệnh ĐTĐ cuối cùng cũng xuất hiện bệnh thận. Bệnh thận ĐTĐ ảnh hưởng đến khả năng của thận trong việc loại bỏ các chất cặn bã và dịch thừa ra khỏi cơ thể. Cách tốt nhất để ngăn ngừa hoặc trì hoãn bệnh thận ĐTĐ là duy trì một lối sống lành mạnh và điều trị bệnh ĐTĐ và tăng huyết áp. Trong nhiều năm, tình trạng này từ từ làm suy yếu hệ thống lọc tinh vi của thận. Điều trị sớm có thể giúp ngăn ngừa hoặc làm chậm sự tiến triển của bệnh và giảm nguy cơ biến chứng. Bệnh thận có thể tiến triển thành suy thận, còn được gọi là bệnh thận giai đoạn cuối. Suy thận là một tình trạng nguy hiểm đến tính mạng. Ở giai đoạn này, lựa chọn điều trị là chạy thận hoặc ghép thận.

Tù khóa: bệnh thận đái tháo đương (ĐTÐ), suy thận

Chịu trách nhiệm chính: Đinh Thị Minh Hảo

Ngày nhận bài:11/1/2020

Ngày duyệt bài: 28/02/2020

Email: minhhaodinh@gmail.com

ĐT: 0905336951

\section{1. ĐẠT VẤN ĐỀ}

Đái tháo đường bao gồm cả type 1 và type 2 gâynhiều biến chứng lên tất cả các cơ quan trong cơ thể: mạch máu, võng mạc, thận, tim mạch,... Biến chứng thận của bệnh Đái tháo đường gồm các biến chứng ở cầu thận (xơ hóa cầu thận gọi tắt là bệnh thận đái tháo đường), bệnh lý xơ vữa mạch máu ở thận, bệnh lý nhiễm trùng thận và đường niệu.

Bệnh thận đái tháo đường là một trong các biến chứng mạn tính do tổn thương mạch máu nhỏ bên cạnh biến chứng võng mạc, biến chứng thần kinh ngoại biên và thần kinh thực vật. Có 35-50\% bệnh nhân ĐTĐ type 1 phát triển BТĐTĐ sau 20 năm, và 10-20\% bệnh nhân ĐТĐ type 2 được phát hiện có protein niệu ngay thời điểm được chẩn đoán. Bệnh thận đái tháo đường cũng là nguyên nhân hàng đầu gây suy thận mạn (STM) giai đoạn cuối tại các nước châu Âu với tỷ lệ thay đổi từ 20-45\% bệnh nhân suy thận mạn giai đoạn cuối. Ở châu Á, theo JSDT (Nhật Bản, 2000), nguyên nhân suy thận giai đoạn cuối được lọc máu chu kỳ do viêm cầu thận đái tháo đường đứng hàng thứ hai sau viềm cầu thận mạn nguyên phát. 
Tuy nhiên, vấn đề chẩn đoán sớm và dự phòng bệnh thận đái tháo đường dường như vẫn chưa được quan tâm đúng mức.

Ở nước ta đến nay chưa có các nghiên cứu quy mô và hướng dẫn cụ thể về điều trị cũng như dự phòng bệnh thận mạn do đái tháo đường.

\section{CÁC YẾU TỐ NGUY CƠ BÊ̂NH THẬN ĐÁI THÁO ĐƯờNG: \\ - Tăng đường huyết không ổn định, \\ - Thời gian mắc đái tháo đường, \\ - Tăng huyết áp và sự kiểm soát huyết áp. \\ - Tăng cholesterol. \\ - Hút thuốc lá. \\ - Di truyền.}

\section{CƠ CHẾ GÂY TỔN THƯƠNG CẦU THẬN TRONG ĐÁI THÁO ĐƯờNG}

- Tăng đường huyết: Tăng đường huyết là điều kiện cần thiết, tuy không phải là duy nhất để cho tổn thương thận phát triển, tổn tại và tiến triển. Ổn định đường huyết làm chậm xuất hiện tổn thương thận ở bệnh nhân đái tháo đường, làm cải thiện và ngăn ngừa tiến triển của tổn thương dẫn đến xơ hóa cầu thận.

- Tăng lọc cầu thận (glomerular hyperfiltration) ở bệnh nhân đái tháo đường, trực tiếp làm tăng lắng đọng các chất ở vùng ngoài tế bào, qua cơ chế tăng bộc lộ TGF- $\beta$, gây căng dãn tế bào trung mô, tăng hoạt hệ renin-angiotensin, và hệ thống protein kinase $\mathrm{C}$.

- Tăng huyết áp thúc đẩy tiến triển bệnh thận do đái tháo đường, ngược lại, kiểm soát tốt huyết áp làm giảm tiến triển đến tiểu albumine và từ tîêu albumine vi thể thành đại thể.

- Di truyền: Bệnh nhân đái tháo đường trong gia đình có tiền sử tăng huyết áp hoặc bệnh tim mạch, sẽ tăng nguy cơ bệnh thận đái tháo đường.

\section{CHẨN ĐOÁN BÊ̂NH THẬN ĐÁI THÁO ĐƯỜNG}

Bệnh thận đái đường hiện nay ở nước ta chưa được quan tâm đúng mức, chưa được dự phòng và chẩn đoán sớm, mà chỉ chẩn đoán khi các triệu chứng lâm sàng đã rõ.

Bệnh thận đái tháo đường (ĐTĐ) được xác định:

*Tiêu chuẩn chính: Có sự xuất hiện của albumine dai dẳng trong nước tiểu $>300 \mathrm{mg}$ $124 \mathrm{~g}$ hoặc 200 microg/ ph (để chính xác, nước tiểu cần thử 3 lần khác nhau trong khoảng thời gian 3-6 tháng).

*Tiêu chuẩn phụ:

- Có sự hiện diện của bệnh lý đáy mắt do ĐTĐ. Không có sự hiện diện của bệnh thận và bệnh đường tiết niệu gây protein niệu.

- Đái tháo đường type 1 ít nhất là 10 năm

Theo Mogensen, người ta phân chia 5 giai đoạn của bệnh cầu thận đái tháo đường:

+ Giai đoạn cường năng - phì đại: tăng tưới máu thận, tăng lọc cầu thận, tăng kích thước thận, bắt đầu có protein niệu.

+ Giai đoạn im lặng(về lâm sàng) với bài tiết albumin niệu bình thường, lọc cầu thận bình thường, kéo dài hàng chục năm.

+ Giai đoạn bệnh thận đái tháo đường bắt đầu đặc hiệu bởi microalbumin niệu thường xuyên, mức lọc cầu thận bình thường hay còn tăng, huyết áp tăng.

+ Giai đoạn bệnh thận đái tháo đường thiết lập ổn định, đặc hiệu bởi protein niệu lâm sàng, huyết áp tăng, mức lọc cầu thận giảm và suy thận nhanh chóng nếu không điều trị.

+ Giai đoạn suy thận nặng, suy thận giai đoạn cuối kèm nhiều biến chứng (mắt, thần kinh, tim mạch). 


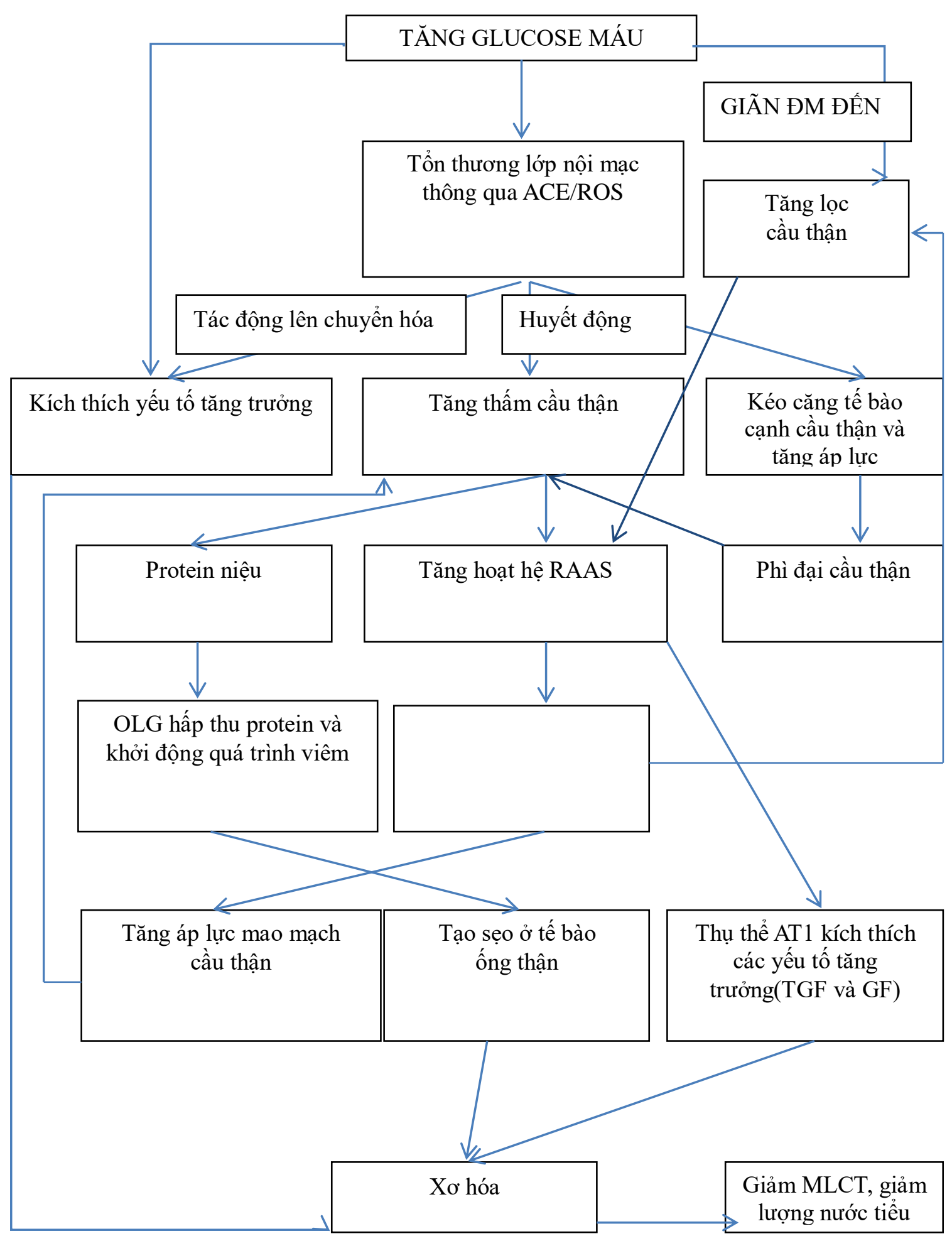

So đồ 1. Cơ chế bệnh thận đái tháo đường 


\begin{tabular}{|c|c|c|c|c|c|c|}
\hline $\begin{array}{c}\text { Giai } \\
\text { đoạn }\end{array}$ & Đặc điểm & Biểu hiện LS & MLCT & Albumin niệu & Huyết áp & $\begin{array}{c}\text { Thời } \\
\text { gian }\end{array}$ \\
\hline $\mathbf{1}$ & $\begin{array}{c}\text { Tăng } \\
\text { chức năng } \\
\text { phì đại }\end{array}$ & $\begin{array}{c}\text { Tăng lọc } \\
\text { cầu thận }\end{array}$ & Tăng & Có thể tăng & $\begin{array}{c}\text { Typ1: bình } \\
\text { thường, typ2: } \\
\text { bình thường } \\
\text { /tăng }\end{array}$ & $\begin{array}{c}\text { Thời } \\
\text { điềm } \\
\text { chẩn } \\
\text { đoán }\end{array}$ \\
\hline $\mathbf{2}$ & Im lặng & $\begin{array}{c}\text { Dày màng } \\
\text { đáy+ giãn tb } \\
\text { cạnh cầu thận }\end{array}$ & $\begin{array}{c}\text { Bình } \\
\text { thường }\end{array}$ & $\begin{array}{c}\text { Typ 1: tăng } \\
\text { Typ2: <30- } \\
300 \mathrm{mg} / \mathrm{dl}\end{array}$ & $\begin{array}{c}\text { Typ1: tăng } \\
\text { Typ2: bình } \\
\text { thường /tăng }\end{array}$ & $\begin{array}{c}5 \text { năm } \\
\text { đầu }\end{array}$ \\
\hline $\mathbf{3}$ & Bắt đầu & $\begin{array}{c}\text { Albumin niệu } \\
\text { vi thể }\end{array}$ & $\begin{array}{c}\text { Bắt đầu } \\
\text { giảm }\end{array}$ & $30-300 \mathrm{mg} / \mathrm{dl}$ & $\begin{array}{c}\text { Typ1: tăng } \\
\text { Typ2: bình } \\
\text { thương/tăng }\end{array}$ & $\begin{array}{c}6-15 \\
\text { năm }\end{array}$ \\
\hline $\mathbf{4}$ & $\begin{array}{c}\text { Ốn định } \\
\mathbf{5}\end{array}$ & $\begin{array}{c}\text { Albumin niệu } \\
\text { đại thể }\end{array}$ & Giảm & $>300 \mathrm{mg} / \mathrm{dl}$ & Tăng & $\begin{array}{c}15-25 \\
\text { năm }\end{array}$ \\
\hline mạn & $\begin{array}{c}\text { Suy thận giai } \\
\text { đoạn cuối }\end{array}$ & $0-10$ & Giảm & Tăng & $\begin{array}{c}25-30 \\
\text { năm }\end{array}$ \\
\hline
\end{tabular}

- 5 giai đoạn của bệnh thận mạn đái tháo đương theo Mogensen.

\section{5. ĐIỀU TRI BỆNH THẬN ĐÁI THÁO ĐU'ỜNG}

\subsection{Mục tiêu điều trị}

+ Kiểm soát tốt tình trạng tăng đường huyết, HbA1C khoảng 7\%.

+ Giảm protein niệu đến $<0,5 \mathrm{~g} / 24 \mathrm{~h}$.

+ Giảm huyết áp mục tiêu $<130 / 80 \mathrm{mmHg}$ ở bệnh nhân GFR > 15ml/ph/ 1,73m2.

+ Kiểm soát lipid máu

+ Theo dõi đồng thời các biến chứng khác.

\section{2. Điều trị cụ thể}

* Điều trị hạ glucose máu

Mục tiêu điều trị:

- HbAlc khoảng 7\% để phòng ngừa và làm chậm tiến triển biến chứng mạch máu nhỏ của đái tháo đường, trong đó có biến chứng thận.

- HbA1C > 7\%: ở những bệnh nhân suy thận, bệnh nhân có nguy cơ cao bị hạ glucose máu, có nhiều bệnh lý đi kèm ảnh hưởng lên đời sống. Cần tránh biến chứng hạ glucose máu làm tăng nguy cơ tử vong cho nhóm bệnh nhân này.

Thuốc điều trị hạ glucose máu:

- Nếu bệnh nhân suy thận (GFR < $60 \mathrm{ml} / \mathrm{ph} / 1,73 \mathrm{~m} 2 \mathrm{da}$ ): cần điều chỉnh liều thuốc hạ glucose máu theo chức năng thận, phương pháp điều trị thay thế thận và tình trạng dinh dưỡng của bệnh nhân. Không dùng
Metformin, insulin tác dụng kéo dài (insulin glargine) ở bệnh nhân suy thận.

- Nếu bệnh nhân đang điều trị thay thế thận: Do glucose được lọc qua màng lọc thận nhân tạo (TNT), nên ngày bệnh nhân chạy thận nhân tạo, nguy cơ hạ đường huyết sẽ tăng, cần giảm liều insulin. Bệnh nhân thẩm phân phúc mạc, với dịch lọc glucose, cần tăng liều insulin chích hoặc dùng insulin trong dịch lọc. Bệnh nhân ghép thận nếu có dùng tacrolimus và steroid, glucose máu dễ tăng cao, hoặc bệnh nhân có nguy cơ dễ bị đái tháo đường do thuốc xuất hiện sau ghép thận.

- Một số thuốc mới được xem là hiệu quả trong bệnh thận đái tháo đường do vừa làm hạ glucose máu, vừa giảm protein niệu: đồng vận GLP-1R, DPP-4I, SGLT-2I, rosiglitazone.

- Insulin:Áp dụng cho bệnh nhân BTĐTĐ đã có suy thận giai đoạn 4-5 ở ĐTĐ TYPE 2. Hiện nay vẫn chưa có bằng chứng nên dùng loại Insulin nào cho bệnh nhân là tốt nhất, nên có thể dùng Insulin như bình thường. Tuy nhiên, Insulin được chuyển hóa ở thận, vì thế ở bệnh nhân bị bệnh thận ĐTĐ nếu đã đến giai đoạn suy thận, thì thời gian bán thải của Insuline kéo dài, hệ quả là bệnh nhân ĐTĐ suy thận khi dùng insulin có nguy cơ hạ glucose máu gấp 5 lần, vì vậy thường sử dụng 
Insulin nhanh ở nhóm này, và luôn theo dõi triệu chứng hạ glucose máu khi sử dụng.

* Điều trị tăng huyết áp: Ủu tiên sử dụng nhóm thuốc ức chế hệ renin angiotensin:

+ Chọn lựa thuốc dùng:

Thuốc ức chế hệ renin-angiotensin có hiệu quả làm giảm albumine niệu, làm giảm tốc độ tiến triển bệnh thận đái tháo đường khi kèm hoặc không kèm tăng huyết áp.

Nếu bệnh nhân đái tháo đường không có albumine niệu và không kèm tăng huyết áp: Không dùng thuốc ức chế men chuyền (UCMC) hoặc ức chế thụ thể angiotensin (UCTT) để phòng ngừa bệnh thận do đái tháo đường.

Nếu bệnh nhân đái tháo đường kèm albumine niệu (với tỷ lệ albumine/créatinine $>30 \mathrm{mg} / \mathrm{g}$ ), không kèm tăng huyết áp, được xem là nhóm có nguy cơ bệnh thận đái tháo đường và có nguy cơ bệnh thận tiến triển: nên dùng thuốc ức chế men chuyển hoặc chẹn thụ thể. Nếu bệnh nhân đái tháo đường type 1 albumine niệu đại thể $(>300 \mathrm{mg} / \mathrm{g})$, ưu tiên chọn thuốc ức chế men chuyển.

Nếu bệnh nhân có tác dụng phụ (như ho) với thuốc ức chế men chuyển, có thể chuyển sang thuốc chẹn thụ thể hoặc ngược lại. Việc phối hợp thuốc ức chế men chuyển với chẹn thụ thể làm tăng hiệu quả giảm protein niệu, nhưng không khuyến cáo vì làm gia tăng tác dụng phụ (suy thận cấp, tăng kali máu).

+ Cách dùng: Do hiệu quả giảm protein niệu tăng theo liều dùng, nên khởi đầu từ liều thấp, tăng dần liều thuốc. Cần theo dõi đáp ứng bằng protein niệu, cũng như tác dụng phụ của thuốc nhất là trên bệnh nhân có GFR < $60 \mathrm{ml} / \mathrm{ph} / 1,73 \mathrm{~m}^{2}$ da: tăng kali máu, suy thận cấp, ho khan, phù mạch. Có thể phối hợp với lợi tiểu.

Việc kiểm soát tốt huyết áp làm chậm tiến triển bệnh thận do đái tháo đường.

*Kiểm soát rối loan lipid máu:

Kiểm soát rối lọan lipid máu làm giảm biến chứng xơ mỡ động mạch ở bệnh nhân đái tháo đường biến chứng thận.

Nguyên tắc và biện pháp điều trị tương tự của hướng dẫn ATP-III chung dành cho người trưởng thành.
Mục tiêu LDL $<100 \mathrm{mg} / \mathrm{dL}$, Non-HDL cholesterol $<130 \mathrm{mg} / \mathrm{dL}$.

Thuốc giảm LDL-Cholesterol như statin hoặc statin phối hợp với eztimibe để làm giảm nguy cơ các biến cố xơ vữa động mạch, bao gồm cả những bệnh nhân đã ghép thận.

Không khởi đầu dùng statin ở bệnh nhân đái tháo đường đã lọc máu, có thể dùng aspirin với mục đích dự phòng ở các bệnh nhân có Cholesterol tăng cao.

Ở những bệnh nhân protein niệu nhiều gây tăng lipid máu thứ phát, như hội chứng thận hư, cần điều trị giảm protein niệu trước khi dùng thuốc hạ lipid.

Nhóm fibrate cần giảm liều khi mức lọc cầu thận $<60 \mathrm{ml} / \mathrm{ph} / 1,73 \mathrm{~m}^{2}$ và không dùng khi mức lọc cầu thận $<15 \mathrm{ml} / \mathrm{ph} / 1,73 \mathrm{~m}^{2}$.

\subsection{Liệu pháp điều trị trong tương lai?}

Hiện nay, trên thế giới có nhiều nghiên cứu quan tâm đến điều trị bệnh thận đái tháo đường, mục tiêu chủ yếu là giảm giai đoạn viêm mạch và sau đó là giảm protein niệu. Một số thuốc và chế phẩm mới như Bardoxolon (chất chống oxy hóa tế bào), Pentoxifilline, Pirfenidone, Vitamin D, chất đối vận thụ thể Endothelin-1, chất kết dính photphat (Sevelamer),... mặc dù vẫn còn phải nghiên cứu tiếp nhưng cũng hứa hẹn mang lại hiệu quả và hy vọng mới cho điều trị bệnh thận đái tháo đường trong tương lai.

\section{CHẾ Độ DINH DƯỠNG VÀ DỰ PHÒNG}

\subsection{Dinh dưỡng}

- Cần kiểm soát cân nặng, tránh thừa cân: hạn chế carbohydrate, giảm mỡ bão hòa, tiết chế đạm nếu có suy thận, protein nhập 0,6 $0,8 \mathrm{~g} / \mathrm{kg} / \mathrm{ngày}$, tiết chế muối nhập $<6 \mathrm{~g} / \mathrm{ngày}$, tập vận động mỗi ngày.

- Bỏ hút thuốc lá.

- Một số thực phẩm bổ sung đã được chứng minh có hiệu quả giúp giảm albumine niệu: Vitamin C 200-1250mg/ngày, vitamin $\mathrm{E}$ 100UI-680UI/ngày, acid lipoic 600mg/ngày.

\subsection{Dự phòng}

Tầm soát bệnh thận đái tháo đường ở mọi bệnh nhân đái tháo đường type 1 sau 5 năm chẩn đoán đái tháo đường, và ngay thời điểm 
chẩn đoán với đái tháo đường type 2.Xét nghiệm tầm soát bệnh thận do đái tháo đường bao gồm: tỷ lệ albumine/ creatinine nước tiểu với mẫu nước tiểu bất kỳ và creatinine huyết thanh để ước đoán GFR. Phối hợp đa chuyên khoa trong chẩn đoán, điều trị và theo dõi bệnh nhân: chuyên khoa thận và chuyên khoa nội tiết, tim mạch, thần kinh...

\section{TÀI LIỆU THAM KHẢO}

1. Nguyễn Thy Khuê, "Biến chứng thận của bệnh đái tháo đường".

2. Hà Hoàng Kiệm, "Bệnh thận do đái tháo đường”, Thận học lâm sàng, NXB Y học 2010, tr.470-479.

3. Nguyễn Văn Tuấn, Võ Tam, "Hướng dẫn thực hành lâm sàng của KDOQI 2012 về bệnh thận mạn đái tháo đường”.
4. Carolina C.R Betonico et al(2016), "Management of Diabetes mellitus in individual with Chronic kidney disease: therapeutic perspectives and glycemic control", Clinics 2016;71(1): 47-53.

5. Eric Wong et al, "Chronic kidney disease", J Am Soc Nephrol, 2008 Apr;19(4):651-3.

6. Evangelia Dounousi et al(2015), "Improvements in the management of Diabetic Nephropathy", Rev Diabet Stud, 2015 Spring- Summer;12(1-2):119133.

7. Lukas Foggensteiner et al(2001), "Management of Diabetic Nephropathy", JR Soc Met, 2001 May, 94(5): 210-217.

8. Vecihi batuman.MD, Romesh Khadori.Md, "Diabetic Nephropathy", Medcape eMedicine updated Dec 18, 2017. 